\title{
Rozwój w świetle podstawowych kategorii myśli Johna Deweya
}

\section{Development in Light of the Basic Categories of Thought of John Dewey}

\begin{abstract}
ABSTRAKT
Rozwój jest bez wq̨tpienia jednym z najważniejszych pojęć towarzyszq̨cych rozważaniom na temat kształcenia, wychowania, edukacji. Każdy pedagog musi na pewnym etapie swojej działalności skonfrontować się z tq wysoce podatnq na interpretacje ideq. Nie uniknqł tego również John Dewey, którego poglądy stały się przedmiotem analizy w niniejszym artykule. Celem tejże publikacji jest rekonstrukcja teorii rozwoju amerykańskiego pedagoga oraz krytyczna refleksja nad niq na podstawie jego prac oraz wybranych dzieł omawiających myśl pedagogicznq i filozoficznq pragmatysty. W poszczególnych częściach publikacji zostały zaprezentowane główne idee zwiqzane z koncepcjq rozwoju Deweya, takie jak wartość instrumentalna, pojęcie nawyku czy demokracja. Przedstawione zagadnienia zostały poddane refleksji przez pryzmat ich implikacji pedagogicznych. Dokonana analiza przedmiotu badań ukazała możliwy kierunek rozwoju jednostek w myśli Deweya, jakim jest rozwój społeczeństwa. Nieunikniona wydaje się konieczność dalszych badań nad pedagogikq amerykańskiego filozofa, aby lepiej zrozumieć i zinterpretować jego idee czy też rozstrzygnąć niejasności, które występuja w jego pismach.
\end{abstract}

SLOWA KLUCZOWE John Dewey, instrumentalizm, rozwój, pragmatyzm, edukacja instrumentalistyczna, nawyk

\section{KEYWORDS}

John Dewey, instrumentalism, development, pragmatism, instrumentalistic education, habit

SPI Vol. 23, 2020/1 ISSN 2450-5358 e-ISSN 2450-5366 DOI: 10.12775/SPI.2020.1.008 Nadestano: 26.03.2020 Zaakceptowano: 4.05 .2020 


\section{ABSTRACT}

Development is undoubtedly one of the most important concepts accompanying considerations on education and upbringing. Every educator must, at a certain stage of his or her activity, confront this highly contestable idea. John Dewey, whose views are the subject of analysis in this article, was certainly not one who would have avoided this. The aim of this publication is to reconstruct the development of the theory of the American educator and to reflect critically on it on the basis of his works and selected works discussing the pedagogical and philosophical thought of the pragmatic scholar. The main ideas associated with Dewey, such as instrumental value, the notion of habit or democracy, are depicted in particular parts of the publication. The presented issues are reflected on through the prism of their pedagogical implications. The analysis of the subject showed the possible developmental directions open to individuals in Dewey's thought, which is the development of society. It seems inevitable that further research on the pedagogy of the American philosopher is needed in order to better understand and interpret his ideas or to resolve the ambiguities that exist in his writings.

\section{Wstęp}

John Dewey wciąż jest autorem, po którego twórczość warto sięgać. Jako jeden $\mathrm{z}$ największych amerykańskich myślicieli (jeśli nie największy), odcisnął trudne do usunięcia piętno na filozofii i pedagogice. Jednakże przede wszystkim przyczynił się do zmiany myślenia zwykłego człowieka. „Siła filozofii Deweya tkwi niewątpliwie w fakcie, że jej autor zawsze miał na uwadze empiryczną rzeczywistość, czyli konkretne sytuacje [...] Dewey sprowadza filozofię na ziemię i usiłuje pokazać jej ważność dla rozstrzygania konkretnych zagadnień moralnych, społecznych i wychowawczych" (Copleston 2009: 333).

Pragmatyzm daje laikowi możliwość uproszczenia filozofii i odniesienia jej do własnego życia. Ludzie, którzy dotąd nie mieli nic wspólnego z tą nauką, w jednym momencie dostali możliwość decydowania o niej, bowiem „Pragmatyzm był wyrazem typowo amerykańskiej niechęci do filozofii czysto spekulatywnej, uważanej za bezużyteczną i jałową" (Gutek 2003: 83). Filozofia stała się dzięki temu systemowi o wiele atrakcyjniejsza dla większości ludzi. 
Pragmatyzm określa się jako filozofię relatywistyczną i taka też jest jej deweyowska odmiana. W twórczości Deweya nie znajdzie się śladu wartości określanych jako ponadczasowe czy absolutne. Odrzucał możliwość ich istnienia, ponieważ takie wartości nie są bezpośrednim przedmiotem ludzkiego działania, a właśnie na działaniu oparł swoją myśl filozoficzną. Jednakże dla badaczy jego twórczości duże pole do interpretacji daje pojęcie rozwoju, które wypracował Dewey. Jeśli ktoś chciałby doszukiwać się u amerykańskiego pedagoga czegoś, co mogłoby zostać zinterpretowane jako wartość absolutna czy też ponadczasowa, to niewątpliwie należy zwrócić się właśnie ku badaniom znaczenia rozwoju.

Rozwój nie jest najszerzej opisaną przez Deweya ideą, choć niewątpliwie jedną z najważniejszych, o ile nie najważniejszą w jego myśli. Pomimo tego wyeksplikowanie znaczenia omawianego pojęcia nie jest łatwym zadaniem. Jak pisze Leszek Koczanowicz, badacze Deweya

[...] narażeni są na dwa niebezpieczeństwa: po pierwsze, decydując się podążać za pewnym hasłem, takim choćby jak ,jaźń”, ryzykują, że stracą z oczu cały szereg interesujących idei, które, choć związane z głównym tematem badania, pojawiać się mogą w zupełnie nieoczekiwanych miejscach; po drugie, liczyć się trzeba zawsze z niespójnościami, wynikającymi zarówno z olbrzymiego materiału, z jakim ma się do czynienia, jak też z wielu teoretycznych zwrotów pojawiających się na drodze życiowej tego myśliciela (Koczanowicz 1994: 87).

Pogląd ten w pewnym stopniu potwierdza fakt, że Józef Pieter, wskazując na najważniejsze publikacje Deweya w redagowanej przez siebie książce Wybór pism pedagogicznych, wymienił ich aż trzydzieści pięć.

$\mathrm{Z}$ powyższych powodów skoncentrowano się w niniejszej publikacji w głównej mierze na najważniejszych dziełach Deweya o tematyce pedagogicznej oraz na niektórych opracowaniach jego twórczości i dążono do wyciągnięcia $z$ nich tego to, co najbardziej odpowiada tematowi niniejszych rozważań, czyli implikacjom pedagogicznym, jakie wynikają z koncepcji rozwoju pragmatysty. 


\section{Instrumentalizm}

Teoria wartości amerykańskiego filozofa jest określana mianem instrumentalizmu, ponieważ opiera się niemal wyłącznie na relacji celu ze środkami do jego realizacji. Określenie „niemal wyłącznie” jest zamierzone, gdyż wbrew powszechnej opinii w pismach Deweya znalazło się miejsce na wartości inne niż instrumentalne.

Pierwszym rodzajem wartości są rzeczy istotne ze względu na same siebie, czyli wartości bezwzględne. „Jeśli jakiś przedmiot - pisze Dewey - ma jedyną w swoim rodzaju niezastąpioną funkcję w doświadczeniu, oznacza charakterystyczne wzbogacenie życia, to wartość jego jest istotna i nieporównywalna" (Dewey 1963: 256), a dalej stwierdza, że ,jak długo jakiś temat przemawia do nas bezpośrednio, nie ma potrzeby pytać o jego przydatność [...]. Wszelki inny pogląd prowadzi do absurdu" (Dewey 1963: 258). Nie jest zatem możliwe wyznaczanie kryteriów dotyczących wyboru wartości bezwzględnej innych niż osobiste zainteresowanie podmiotu daną rzeczą.

Drugiego rodzaju wartości, czyli wartości instrumentalne, podlegają ocenie ze względu na zewnętrzne kryterium, jakim zgodnie z ideą pragmatyzmu jest skuteczność (Miś 2002: 47). Pierwotnie wartościować znaczy cenić (prize) i odnosi się to do wartości samej w sobie, natomiast wtórnie oznacza czynność oceniania - instrumentalizację wartości (apprize) (Dewey 1963: 254). W związku z tym instrumentalizm nie powinien być określany jako teoria wartości, lecz teoria wartościowania.

Charakter wartości instrumentalnej polega na wyznaczeniu celu oraz środków do jego realizacji. W instrumentalizmie Deweya pojawia się kategoria wyłącznie celów konkretnych dostosowanych do danej sytuacji. „Problemem, jaki Dewey chce rozstrzygnąć, jest [...] odpowiedź na pytanie, na czym polega wartość w konkretnej sytuacji życiowej" (Gałkowski 2003: 91).

W ramach wartościowania instrumentalnego można wyróżnić dwa sposoby na określenie skuteczności danej wartości. W pierwszym sposobie wartości niepodlegające ocenie ze względu na cel, czyli wartości bezwzględne, są warunkiem koniecznym do przejścia od cenienia sobie danej rzeczy do oszacowywania jej wartości względem jej skuteczności, bowiem w przypadku uczniów „zarówno arytmetyka, jak i poezja w pewnym miejscu i w pewnym czasie powinny 
być dobrem ocenianym ze względu na nie same [...]. W przeciwnym wypadku [...], ponieważ nigdy nie ujmowaliśmy ani nie ocenialiśmy dla nich samych, nie będą mogły służyć jako środek do innych celów" (Dewey 1963: 256). Wynika z tego, że warunkiem wartościowania instrumentalnego jest ujęcie $\mathrm{w}$ jego ramy wartości istotnych przez samą swą istotę, ponieważ w przeciwnym wypadku nie będziemy w stanie dostatecznie ocenić danej wartości ze względu na wcześniejszy brak jej oceny. Skąd człowiek może wiedzieć, że jakaś rzecz jest w jakimś sensie lepsza od drugiej, skoro ich nigdy nie użył?

Nie jest tym samym prawdą, jak to stwierdziła Hanna Buczyńska-Garewicz w swoich badaniach nad pragmatyzmem, że

[...] zasadnicza teza Deweya z teorii wartości głosi, że nic nie może być wartością samo przez się, lecz jedynie ze względu na coś innego, jako środek do jego realizacji, czyli że nie ma wartości innych poza instrumentalnymi (Buczyńska-Garewicz 1970: 284).

Dla osoby przymierającej głodem jedzenie jest dobrem samym w sobie, jak stwierdza Dewey, i nie trzeba uświadamiać jej pożytku $\mathrm{z}$ jedzenia. Natomiast, gdy osoba nie ma żadnej nagłej potrzeby, ale za to musi dokonać wyboru pomiędzy dwiema istotnymi dla siebie wartościami, np. pomiędzy słuchaniem muzyki a oglądaniem filmu, pojawia się wartościowanie instrumentalne przez ocenę ewentualnych skutków określonej wartości.

Drugi rodzaj wyznaczania wartości instrumentalnej nie polega na porównywaniu, lecz na jej bezpośrednim wyprowadzeniu z działania. Według Deweya polega to na zastosowaniu metody eksperymentalnej, której skutkiem jest osiągnięcie wartości instrumentalnej, znajdującej zastosowanie w podobnych sytuacjach. W obu przytoczonych przypadkach wyznacza się środki do realizacji określonego celu, który „nie jest niczym trwałym ani ogólnym, jest wytworem doraźnej sytuacji i jej potrzeb" (Buczyńska-Garewicz 1970: 284).

Punktem wyjścia tej metody jest doświadczenie. Dewey rozważania nad nową filozofią wychowania rozpoczął od stworzenia nowej koncepcji doświadczenia, która miała się stać od tej pory najbardziej wartościowym sposobem poznania. Pisał on, że

[...] zasadnicza jedność nowszej filozofii wychowania zawiera się w koncepcji, że istnieje bliska i konieczna relacja pomiędzy procesami rzeczywistego doświadczenia i edukacji. Jeżeli to prawda, to pozytywny 
i konstruktywny rozwój tej filozofii zależy od poprawnej koncepcji doświadczenia (Dewey 2014: 34).

Zdaniem Deweya istnieją dwa jego rodzaje. Pierwszy z nich jest w swej istocie niekognitywny, to znaczy, że umysł nie jest świadomie zatrudniany do poznawania rzeczywistości. „Dewey zaczyna [więc] od całkowitego zignorowania pojęcia "doświadczenia» jako świadomego, poznawczego, bezpośredniego jawienia się czegoś w indywidualnym umyśle" (Gutowski 2002: 159). Mowa tu o doświadczeniu pierwotnym, które człowiek zdobywa przez samo swe istnienie niezależnie od swojej woli. Dziecko, u którego nie wykształciła się jeszcze świadomość, poznaje świat właśnie dzięki temu rodzajowi doświadczenia. Krótko mówiąc, doświadczenie pierwotne jest biernym i nieuświadomionym sposobem poznawania świata.

Wraz z pojawieniem się świadomości w umyśle człowieka następuje możliwość korzystania z drugiego rodzaju doświadczenia, zwanego refleksyjnym czy eksperymentalnym lub też metodą eksperymentalną, która jest najbardziej efektywnym sposobem poznania w ujęciu Deweya (Dewey 1988: 98-109; 187-194). Metoda ta jest aktywnym sposobem nabierania doświadczenia - wynikiem woli podmiotu. Amerykański pedagog wyróżnił pięć etapów tejże metody. Są to: 1) pojawienie się w życiu podmiotu pewnej sytuacji problemowej, 2) wstępna analiza i interpretacja tejże sytuacji, 3) przegląd rozwiązań owej sytuacji problemowej, które mogłyby się okazać skuteczne, 4) skonstruowanie hipotezy umożliwiającej rozwiązanie problemu oraz 5) wcielenie w życie własnych ustaleń i próba ich weryfikacji (Dewey 1963: 162-163).

Dewey, jak widać, tworzy specyficzną relację pomiędzy teorią poznania a teorią wartościowania, a wręcz scala obie teorie w jedną. Jak pisze Buczyńska-Garewicz,„Pragmatyzm przekształca rzeczywistość faktów i zdarzeń w universum wartości” (Buczyńska-Garewicz 1970: 241). Poznać, oznacza w tym ujęciu dostrzec jakiś fakt, rzecz czy ideę, by następnie rozpoznać w nich ich użyteczność. Ponadto, skoro podstawowym warunkiem ujęcia czegoś jako wartość instrumentalna jest tego skuteczność, to ta wartość pojawia się tylko i wyłącznie w sferze działań człowieka. „Sens instrumentalnej logiki polega na tym, by wykazać, że poznanie jest rodzajem praktycznego działania" (Buczyńska-Garewicz 1970: 284). 


\section{Edukacja instrumentalistyczna}

Jako że instrumentalizm deweyowski zakłada najpierw poznanie, a dopiero potem wartościowanie, istotną rolę odgrywa szkoła. W szczególny sposób Dewey skupiał się na programie nauczania, ponieważ wartości, w myśl opisywanej koncepcji, będą zależne od tego, jaką człowiek posiądzie wiedzę. Za podstawowe zadanie amerykański pedagog uważał wyznaczenie odpowiednich celów, bowiem to od nich zależy, w jaki sposób zostanie pokierowane działanie. W związku z tym skonstruował kryteria, które należy wziąć pod uwagę, konstruując cele.

Pierwszym z kryteriów jest wyrastanie celów z określonych warunków, które dotyczą podmiotu - cel musi być osadzony w doświadczeniu człowieka. W przeciwnym wypadku takie cele „ograniczają inteligencję, ponieważ jeśli dane są gotowe, muszą być narzucone przez jakiś autorytet poza inteligencją, pozostawiając jej tylko mechaniczny dobór środków" (Dewey 1963: 114). Cel narzucony z zewnątrz pozbawia, zdaniem Deweya, możliwości refleksji nad nim.

Edukacja instrumentalistyczna powinna zatem bazować na dotychczasowych doświadczeniach uczniów (pierwotnych bądź refleksyjnych). Istotne $\mathrm{w}$ procesie edukacyjnym jest zdiagnozowanie nie tylko zasobów indywidualnych dziecka, ale także środowiska, z którego się wywodzi, ponieważ to nim najpewniej jest bezpośrednio i żywo zainteresowane. Dewey wychodzi z założenia, że nie ma sensu nauczanie materiału całkowicie nowego bez jakiegokolwiek zaplecza osobistego dziecka, to znaczy bez uwzględnienia jego umiejętności czy warunków domowych. Amerykański pedagog stwierdza, że powinna zachodzić bezpośrednia ciągłość materiału nauczania i indywidualnego doświadczenia dziecka zarówno w celu rozwijania doświadczeń dotychczasowych, jak i kreowania na ich podstawie nowych (Dewey 2014: 66). „Cel wychowawczy musi opierać się na istotnych czynnościach i potrzebach danej jednostki, która ma być wychowywana" (Dewey 1963: 118).

Kolejnym kryterium jest plastyczność celu, co oznacza możliwość jego zmiany w momencie wystąpienia pewnych okoliczności niepozwalających na jego osiągnięcie. Cel powinien być zatem tak konstruowany, by był osiągalny dla człowieka, który go wyznaczył (Dewey 1963: 114). Plastyczność musi być podporządkowana wychowankowi, 
co oznacza, że cel ma wychodzić bezpośrednio od dziecka i być jemu podporządkowany $\mathrm{w}$ taki sposób, aby mógł zostać zmodyfikowany w zależności od okoliczności. Dążenie wychowanka do celu, którego nie można poddać zmianom, wyrządza szkodę dziecku przez nieuwzględnienie specyficznych warunków i kontekstów, do których taki cel może nie być odpowiednio dostosowany. „Błąd narzucania celów z zewnątrz jest głęboko zakorzeniony. Nauczyciele otrzymują je od wyższych władz; władze przyjmują z tego, co jest popularne w społeczności. Nauczyciele narzucają je dzieciom” (Dewey 1963: 119).

Ostatnim kryterium jest zdolność celu do aktywowania działalności ludzkiej. Co więcej, to właśnie działanie jest przez amerykańskiego pedagoga uznawane za prawdziwy cel. „Ściśle mówiąc, nie tarcza, ale trafienie w tarczę [czynność trafienia w tarczę - przyp. B.K.] jest zamierzonym celem" (Dewey 1963: 115). Prawdziwie wychowawczy cel musi wyzwalać czynność. Oznacza to, że musi być realizowalny, ponieważ postawienie celu, którego człowiek nie osiągnie, nie ma najmniejszego sensu. Kryterium to wiąże się z dwoma poprzednimi. Po pierwsze, jeśli cel ma zostać wcielony w życie, powinien się opierać na aktualnych zasobach człowieka. Po drugie, aby cel mógł być możliwy do realizacji, musi podlegać pewnym modyfikacjom.

Zasadniczą cechą celu w rozumieniu Deweya jest jego zależność od dostępnych środków (Buczyńska-Garewicz 1970: 300). Każde z podanych kryteriów łączy to, że bierze pod uwagę środki, jakie są dostępne jednostce. Dlatego też Dewey był sceptycznie nastawiony do celów, które zostały wyznaczone wbrew zasobom posiadanym przez człowieka. Niewątpliwie posiadanie celu jest czymś pożądanym, gdyż oznacza to, „że pewna działalność staje się inteligentną działalnością. Oznacza szczególnie przewidywanie alternatywnych konsekwencji związanych z działaniem w danej sytuacji w różny sposób i zużytkowanie tego, co się przewiduje, dla bezpośredniej obserwacji i eksperymentu" (Dewey 1963: 121). Niemniej jednak postawienie celu do realizacji nie zawsze jest równoznaczne $\mathrm{z}$ działaniem inteligentnym. Działalność staje się inteligentna dopiero w momencie, gdy w wyznaczaniu celu biorą udział dostępne środki. Można wyobrazić sobie jakiś wzniosły cel, np. uczynienie z recydywisty obywatela przestrzegającego prawa i norm społecznych, lecz postawienie tego celu będzie niczym, dopóki nie odpowie się na pytanie, czy osoba taka posiada środki do tego, aby ten cel zrealizować. 
Szkoła jest tą instytucją, która w sposób bezpośredni, celowy i zorganizowany jest w stanie zrealizować program instrumentalistycznej edukacji. Dewey oparł zakres swojego programu nauczania głównie na geografii i historii, ponieważ te dwa przedmioty reprezentują najbliższe dla człowieka obszary jego działań: naturalne oraz społeczne. Uczenie się materiału obu tych przedmiotów zmierza nie tylko do zdobycia określonych informacji, ale przede wszystkim do ich wykorzystania w praktycznej, codziennej działalności człowieka poprzez nadanie im wartości instrumentalnej.

Geografia uwidacznia przede wszystkim specyficzne związki człowieka z przyrodą. „Nie można zrozumieć różnic cywilizacji w krajach zimnych i tropikalnych, specjalnych wynalazków, przemysłowych i politycznych ludów w krajach umiarkowanych - bez odwołania się do Ziemi jako części systemu słonecznego" (Dewey 1963: 228). Działalność ludzka w takim ujęciu jest silnie powiązana z czynnikami przyrodniczymi. Historia zajmuje się natomiast badaniem genezy współczesności. „Znajomość historii jest kluczem do zrozumienia teraźniejszości" - stwierdza Dewey (Dewey 1963: 229) i dodaje, że „Czymkolwiek by była historia dla historyka-naukowca, dla wychowawcy musi być ona pośrednią socjologią - nauką o społeczeństwie, która odsłania nam procesy jego stawania się i sposoby jego organizacji”'(Dewey 1967: 83).

Oba przedmioty są ze sobą ściśle powiązane, tak że można ich uczyć jednocześnie za pomocą metody eksperymentalnej. W chicagowskiej szkole eksperymentalnej, zorganizowanej wedle zamysłu Deweya, prowadzono zajęcia z tkactwa, by ukazać dzieciom rozwój społeczny z perspektywy przemysłu włókienniczego. Rozdawano dzieciom len, wełnę i bawełnę, żeby najpierw zapoznały się z materiałami, a następnie przystąpiły do ich obróbki, dzięki czemu uczniowie $z$ czasem odkrywali specyficzne związki pomiędzy zachowaniem a sposobem ubioru i rodzajem materiału. Historia została w ten sposób ześrodkowana wokół naturalnych surowców włókienniczych oraz miała pomóc w zrozumieniu przyrodniczego i społecznego kontekstu rozwoju ludzkości (Dewey 1967: 84). Widać więc, że deweyowski system nauczania podkreśla również istotność robót ręcznych w szkole. Zajęcia oparte na manualnych metodach dydaktycznych mają mieć swoje uzasadnienie $\mathrm{w}$ tym, że poznanie jako wartościowanie urzeczywistnia się w praktycznej działalności. Ponadto, jak zauważył Dewey, 
„Świat, w którym większość z nas żyje, jest światem, w którym każdy ma jakiś zawód i zajęcie, ma coś do roboty”(Dewey 1967: 87).

Główną intencją wykorzystywania metody eksperymentalnej w szkołach nie jest przekazywanie uczniom wiedzy, ponieważ ta, wraz z upływem czasu, zmienia się. To, co było uznane za prawdziwe w jednym okresie, w następnym może być uważane za szkodliwy zabobon. Dewey skupił się na doświadczeniu refleksyjnym nie dlatego, że jest to najlepszy sposób przekazywania wiedzy, ale z powodu tego, iż jest to, jego zdaniem, najlepszy sposób jej zdobywania. Sposób kształcenia jest wedle tego podejścia znacznie ważniejszy od treści kształcenia, czyli prawdziwym celem w edukacji jest czynność (metoda) uczenia się. Uczniowie w takiej szkole mieliby za zadanie sami zdobywać wiedzę, tak jak to było w przypadku wspomnianych zajęć z tkactwa.

Szkoła ma więc za zadanie, według myśli Deweya, wyposażyć uczniów w metodę skutecznego funkcjonowania w świecie - miałaby uczyć aktywnego działania. Jednakże to, co miało być siłą w edukacji pragmatysty, okazuje się również jej słabością. Filozof nie uwzględnia bowiem w swych rozważaniach „stanu spoczynku”. Jest to konsekwencją przyjęcia przez niego działania jako najważniejszej kategorii w swojej antropologii (Koczanowicz 1994: 92). Ciągła aktywność staje się jedynym sposobem istnienia i stawania jednostki oraz zewnętrznego wobec niej świata. „Dzieci w szkole Deweyowskiej pisze Pieter - wciąż tylko myślą, manipulują, zbierają «społeczne doświadczenia»; nie cieszą się, nie bawią, nie leniuchują" (Dewey 1967: LXXVI). Można w tym miejscu wskazać na pewien poważny błąd zawarty w filozofii Deweya, bowiem „aktywizm, odmawiając ludziom prawa do używania chwili, pozbawia samo działanie sensu bo działamy po to, aby coś uzyskać, nie aby działać dla działania bez końca" (Bocheński 1994: 15).

Celem ciągłego działania miałoby być znalezienie sposobu na lepsze, bardziej wydajne działanie oraz ciągłe przystosowywanie się do zmieniającego świata i przekształcanie go na swoje potrzeby. Skoro zatem jakaś czynność w pewnych sytuacjach może zostać uznana za skuteczną, to nic nie stoi na przeszkodzie, aby stała się ona nawykiem działania. 


\section{Nawyki}

Posłużenie się metodą eksperymentalną w celu wywiedzenia wartości z badania daje człowiekowi możliwość przeistoczenia tejże wartości w nawyk. Jak zauważył Copleston, „Dewey podkreśla jednak, że działanie, skierowane świadomie na cel, który podmiot działania uznaje za wartościowy, zakłada istnienie nawyków jako nabytych dyspozycji do pewnych sposobów reagowania na pewne klasy bodźców" (Copleston 2009: 323).

Nawyk według Deweya jest to „czynna kontrola środowiska przez kontrolę organów działania, [...] czynna kontrola nad środkami do osiagnnięcia celu" (Dewey 1963: 54). Copleston dodaje za Deweyem, że „Całe życie moralne [...] trzeba ukazywać jako rozwój wzajemnego oddziaływania organizmu ludzkiego i jego środowiska" (Copleston 2009: 324). Kształcenie szkolne miałoby więc polegać na wyposażeniu uczniów w umiejętność nabywania nawyków kształtowania środowiska naturalnego (geografia) oraz społecznego (historia), co ma zagwarantować metoda eksperymentalna. Nawyk wywiedziony z doświadczenia refleksyjnego jest więc wartością instrumentalną staje się skutecznym postępowaniem.

Należy wyjaśnić, że Dewey przez nawyk rozumiał jedynie czynność, która została ustanowiona w sposób świadomy i racjonalny. W takim ujęciu nawyku nie mieściły się nawyki zrutynizowane, czyli bezmyślnie powtarzane czynności, często nieświadome oraz wszelkiego rodzaju nałogi (Dewey 1963: 57). Poprawny nawyk Dewey uważał za rozumny.

Nawyki w przypadku środowiska naturalnego oznaczają skuteczne przystosowywanie go do własnych potrzeb. Dewey twierdził, że właśnie aktywna strona nawyku odróżnia społeczeństwa dzikie, które jedynie biernie adaptują się do środowiska, od społeczeństw cywilizowanych, aktywnie przekształcających otocznie naturalne do własnych potrzeb. Czynnikiem ustanawiającym określony nawyk jest stopień, w jakim pozwala on ludziom przekształcić otoczenie do własnych potrzeb. Podobnie wygląda sprawa w kwestii nawyków zmieniania zwyczajów panujących między ludźmi, których nie da się już uzasadnić ich skutecznością.

Widać wyraźnie, że dla Deweya znacznie ważniejsza była aktywna strona postępowania człowieka, $\mathrm{z}$ czym ściśle wiąże się 
doświadczenie refleksyjne. Nawyki działania tworzą się na skutek uznania, że formuła starego nawyku wyczerpała się i nie spełnia on już swoich dotychczasowych funkcji. Pojawienie się w życiu jednostki sytuacji, w której nie może zostać wykorzystany znany jej nawyk, stawia ją w obliczu niepewności i wyzwala spontaniczny impuls, czego efektem jest improwizowane reagowanie na problemowy bodziec. W tym miejscu powinna dojść do głosu metoda eksperymentalna, której celem jest modyfikacja starego nawyku lub wytworzenie nowego. Metoda ta nie tylko umożliwia zdobycie nawyku działania - ona sama powinna być nawykiem działania.

Dewey stwierdza, że „nabywanie nawyków wypływa z wrodzonej plastyczności naszej [ludzkiej - przyp. B.K.] natury" (Dewey 1963: 57). Nawyki istnieją, są modyfikowane, zanikają czy też zmieniają się dzięki temu, że człowiek jest istotą plastyczną. Łukasz Nysler pisze, rekonstruując poglądy Deweya, że

[...] natura ludzka jest plastyczna, niedookreślona, niekompletna, otwarta oraz wymaga dopełnienia, dookreślenia, rozwinięcia i uformowania w procesach interakcji jednostki z jej fizycznym, organicznym, a przede wszystkim z jej społecznym oraz kulturowym otoczeniem (Nysler 2007: 60-61).

Wychowankowie w trakcie edukacji, w myśl tej koncepcji, zostają wyposażeni w metodę eksperymentalną, rozumianą nie tylko jako narzędzie do zdobywania wiedzy, ale także jako narzędzie do formowania samych siebie. W podobnym tonie opisywana jest jaźn w ujęciu pragmatysty. „Jaźń należy dlatego rozpatrywać jako pewien proces, który ujawnia się $\mathrm{w}$ działaniu, a nie jako istotę czy naturę człowieka” (Koczanowicz 1994: 104). Człowieka w tej koncepcji należy traktować jako istotę ciągle aktualizującą się, której stałość jest jedynie instrumentem do przejścia w nową formę jaźni. Bez nawyków człowiek nie może się stać tym, kim jest - jego natura jest więc rozpatrywana w kontekście ciagłej zmiany, ale zmiany jakościowej, która jest rozwojem, czyli ciągłym nabywaniem lub modyfikowaniem nawyków aktywnego funkcjonowania w świecie.

„Moralnym problemem - pisze Dewey - zarówno u dzieci, jaki u dorosłych jest wykorzystanie impulsów i instynktów do kształtowania nowych nawyków albo modyfikacji starych" (Dewey 1922: 104), ponieważ „impulsy są modyfikowane przez społeczne interakcje" (Koczanowicz 1994: 104). Co więcej, zdaniem amerykańskiego 
pedagoga, „wzrastanie jest jedynym moralnym celem” (Dewey 1920: 173), a więc moralność sprowadza się wyłącznie do nabywania rozumnych nawyków, ponieważ ich istotą jest rozwój człowieka - są one wyrazem rozwoju (Dewey 1963: 54). Bez kategorii nawyków nie można mówić o deweyowskiej koncepcji edukacji.

Jak widać, nabywanie nawyków jest w ujęciu Deweya rozwojem, natomiast rozwój można utożsamić $\mathrm{z}$ wychowaniem (Dewey 1963: 59). Stąd wynika, że wychowanie „staje się wyłącznie coraz skuteczniejszym procesem przystosowania do panujących warunków, zaspokajania własnych potrzeb oraz nabywania umiejętności rozwiązywania problemów, jakie pojawiają się przed człowiekiem" (Gałkowski 2003: 216-217). Proces ten przypomina nieustanne eksperymentowanie, w wyniku którego człowiek nabywa rozumnych nawyków. „Wychowanie określa się często jako proces polegający na nabywaniu tych nawyków, dzięki którym następuje przystosowanie jednostki do środowiska” (społecznego i naturalnego) (Dewey 1963: 54). „Tak więc docieramy do technicznej definicji wychowania: jest to rekonstrukcja czy reorganizacja doświadczenia, która pomnaża znaczenie doświadczenia i zwiększa zdolność kierowania biegiem późniejszego doświadczenia" (Dewey 1963: 86). Ta rekonstrukcja odbywa się poprzez nabywanie i modyfikowanie nawyków.

Metoda eksperymentalna, jak widać, ma niezwykle szerokie zastosowanie. Kreuje doświadczenie człowieka, daje możliwość zdobywania wiedzy, determinuje sferę wartości czy moralności. Amerykański pedagog pisze, że „Niewątpliwie dużo upłynie czasu, zanim ugruntuje się przekonanie, że dotyczy ona [metoda eksperymentalna - przyp. B.K.] również problemów społecznych i moralnych, jeśli chodzi o sprawdzanie i kształtowanie pojęć" (Dewey 1963: 358). Najważniejsze jest jednak to, że doświadczenie refleksyjne bierze bezpośredni udział we wzrastaniu człowieka $\mathrm{z}$ racji nabywania dzięki tej metodzie nawyków działania.

\section{Rozwói-dojrzałość - niedojrzałość}

Wiodąca teza teorii rozwoju Deweya brzmi: „Nie istnieje nic, do czego by rozwój zmierzał prócz tylko dalszego rozwoju” (Dewey 1963: 59), a zatem nie istnieje nic, do czego by wychowanie zmierzało 
prócz tylko dalszego rozwoju wychowanka. To proste stwierdzenie wymaga jednak znacznego uzupełnienia.

Rozwój człowieka następuje tylko pod warunkiem, że jest się w pewnym aspekcie niedojrzałym. Osoba niedojrzała posiada, zdaniem Deweya, dwie zasadnicze cechy: zależność i plastyczność. „Ze społecznego punktu widzenia zależność oznacza raczej siłę niż słabość, pociąga bowiem za sobą wzajemną zależność" (Dewey 1963: 52). Tak rozumiana zależność wykształca w człowieku świadomość potrzeby życia we wspólnocie, a w konsekwencji wrażliwość na życie społeczne. Druga cecha niedojrzałości, plastyczność, oznacza „zdolność modyfikowania czynności na podstawie rezultatów poprzednich doświadczeń" (Dewey 1963: 52), dzięki czemu człowiek ma możliwość dostosowywania czynności do konkretnych sytuacji.

Stwierdzenie, że rozwój jest celem samym w sobie, oznacza odrzucenie wszelakich celów zewnętrznych wobec wychowania. Przede wszystkim chodzi tu o osiągnięcie dojrzałości. Być dojrzałym, znaczy być uformowanym, gotowym do pełnego funkcjonowania (Dewey 1963: 50), a osiągnięcie tego stanu nie wymagałoby dalszego rozwoju. Osiągnięcie dojrzałości, czyli stagnacja, jest przeciwieństwem rozwoju. Stawiając dojrzałość za cel wychowania, problematyczne staje się wyznaczenie jego kryteriów. Kiedy można uznać, że osoba osiągnęła dojrzałość? Odpowiedź na to pytanie przysparza niezwykle wiele problemów i sprzeczności. Można się kierować w tym przypadku kryteriami prawnymi, ale ich Dewey w swych pismach w ogóle nie brał pod uwagę. Za Stownikiem jezzyka polskiego PWN można przyjąć, że człowiek dojrzały to człowiek „ukształtowany pod względem umysłowym i emocjonalnym" (por. https://sjp.pwn.pl/slowniki/ dojrzałość.html [dostęp: 10.12.2019]). Definicja ta zmusza czytelnika do odpowiedzenia na pytanie o moment, w którym osoba staje się „ukształtowana pod względem umysłowym i emocjonalnym”. W oczywisty sposób nie da się dać jednej odpowiedzi, a tym bardziej prawidłowej, bowiem umysł i emocje człowieka są w niewielkim stopniu mierzalnymi wskaźnikami, a w dodatku słabo poznawalnymi pomimo ciągłego rozwoju badań naukowych. Tych trudnych do rozwiązania kwestii starał się uniknąć Dewey, tworząc własną teorię rozwoju, która jednak, jak zauważył Stanisław Gałkowski, zawiera w sobie pewną sprzeczność, gdyż zgodnie z nią za najbardziej rozwinięte trzeba by uznać małe dziecko. 
Jeżeli, jak twierdził Dewey, rozwój polega na nabywaniu umiejętności, nawyków, to ludzie, którzy je nabędą, definitywnie zamykają sobie drogę do osiągnięcia umiejętności konkurencyjnych, jako że „Pięcioletnie dziecko może zostać fizykiem albo sztangistą [...]. Trzydziestoletni geniusz matematyczny nie ma już takich możliwości” (Gałkowski 2003: 103). Jeśliby przyjąć ten punkt widzenia, to dorosły podjątby najlepszy krok, pozostając $\mathrm{w}$ „btogostawionym stanie dzieciństwa, aby nie zmniejszać możliwości rozwojowych" (Gałkowski 2003: 103) i w związku z tym zachowałby szansę na realizację swoich potencjalności, bowiem - jak pisze Dewey - to „niedojrzałość oznacza pozytywną siłę albo zdolność - własność rozwoju” (Dewey 1963: 50).

Rozstrzygnięciem tego problematycznego zagadnienia mogłoby być odwołanie się do nawyków. Otóż nawyki, jak wcześniej wyjaśniono, są wskaźnikami rozwoju człowieka. Nabywanie ich jest wyznacznikiem realizacji potencjalności drzemiących w człowieku. Niemniej jednak nawyki nie są czymś biernym, dzięki czemu człowiek przystosowuje się do sytuacji, lecz aktywną częścią jego działalności w świecie: „Nawyk nie czeka [...] na pojawienie się bodźca [...] nawyk aktywnie szuka okazji, by przejść do pełnego działania" (Dewey 1963: 56). Pojawia się więc wniosek, że deweyowska plastyczna natura ludzka nie jest człowiekowi dana, lecz jest mu przede wszystkim zadana i w jego interesie leży sposób, w jaki ją wykorzysta. Wniosek ten oznacza, że plastyczna natura ludzka nie może być jedynie zbiorem potencjalności, ponieważ samo ich posiadanie jest niczym, dopóki nie dąży się do ich realizacji. Miara, jaką mierzy się wartość rozwoju dorosłych, zawiera się właśnie $\mathrm{w}$ dążeniu dorosłych do realizacji swoich zdolności, podczas gdy dzieci zdolności jedynie posiadają i nie zawsze są ich świadome. $Z$ tego powodu to na dorosłych spoczywa odpowiedzialność za rozwój dzieci, bowiem to oni są w stanie dostrzec zdolności młodych i odpowiednio nimi pokierować lub zapewnić środki do ich realizacji.

Tak długo jak człowiek nie podejmie aktywnych działań w kierunku realizacji potencjalności, czyli nabywania rozumnych nawyków w swych zdolnościach, niedojrzałość nie może być pojmowana w sensie absolutnym. $Z$ tego wynika, że „zarówno normalne dziecko, jak i normalny dorosły rozwijają się. Różnica między nimi nie jest różnicą pomiędzy wzrastaniem a brakiem wzrastania, lecz różnicą form rozwoju, odpowiednich do różnych warunków" (Dewey 1963: 58). 


\section{Społeczne warunki rozwoju}

Dewey był przekonany, że dopóki nie określi się kształtu społeczeństwa, do którego młodzi mają zostać włączeni, dopóty nie jest możliwe określenie znaczenia wychowania (Dewey 1963: 106). Swój autorski system pedagogiczny ujmował jako demokratyczną koncepcję wychowania. Demokracja była dla niego nie tylko sposobem rządzenia, ale także sposobem organizacji stosunków społecznych, który zapewnia najlepsze warunki do rozwoju z powodu występowania w niej charakterystycznych stosunków społecznych opartych na wspólnym interesie i współdziałaniu (Dewey 1963: 92; 96).

Pierwsza $\mathrm{z}$ cech nie polega na wyborze jakiegoś jednego celu, którym zainteresowani byliby członkowie grupy. Chodzi raczej o to, że wspólnym interesem grupy jest posiadanie wielu wspólnych interesów. „Musi istnieć duża różnorodność podzielanych przedsięwzięć i doświadczeń. W przeciwnym razie wpływy wychowujące jednych na panów - wychowują innych na niewolników” (Dewey 1963: 50). Różnorodność podzielanych celów daje jednostce możliwość ciągłego poznawania nowości; nowości z kolei pobudzają myślenie, a więc dają sposobność do nabycia większej liczby rozumnych nawyków (Dewey 1963: 94). Współdziałanie ma natomiast zapewnić przepływ interakcji pomiędzy jednostkami oraz wspólnotami, ponieważ, jak twierdził Dewey, „izolacja prowadzi do sztywności i formalnego zinstytucjonalizowania życia dla statycznych i samolubnych ideałów w obrębie grupy" (Dewey 1963: 95). Interakcja, podobnie jak wielość wspólnych interesów, zapoznaje człowieka z nowymi doświadczeniami.

Amerykański pedagog pisze:

Społeczeństwo jest o tyle demokratyczne, o ile zapewnia wszystkim członkom udział w swoim dobru na równych prawach i o ile zapewnia giętkie przystosowanie swych instytucji dzięki współdziałaniu różnych form życia zrzeszonego (Dewey 1963: 109).

Istotna jest pierwsza część przytoczonego cytatu, w której to zawarta jest sugestia, że nie wystarczy jedynie wprowadzenie demokracji, ale potrzebna jest również jakaś forma egalitaryzmu ekonomicznego. W innym miejscu filozof stwierdza:

System szkolny musi mieć zapewnioną taką rozległość i taką wydajność, które by faktycznie, a nie tylko nominalnie, zniwelowały skutki 
nierówności ekonomicznej i zapewniły wszystkim wychowankom narodu jednakowe wyposażenie do przyszłej kariery (Dewey 1963: 108).

Wskazuje to na jakiś rodzaj socjaldemokratycznego systemu społeczno-ekonomicznego.

Jak widać, sama niedojrzałość nie wystarczy do tego, aby człowiek był zdolny do rozwoju. Potrzebny jest do tego kolejny warunek, czyli odpowiednio zorganizowane społeczeństwo i to społeczeństwo demokratyczne oparte na zasadach wspólnych interesów i współdziałania. Innym warunkiem rozwoju jest podporządkowanie się metodzie eksperymentalnej. Jej zastosowanie w dydaktyce ukazuje jednak pewną niekonsekwencję w myśli Deweya. Chcąc wyrwać pedagogikę z karbów herbartyzmu i przeciwstawić się jednostronnej metodzie nauczania, wprowadził ją w drugą jednowymiarową metodę - tylko dzięki doświadczeniu refleksyjnemu człowiek może w tym ujęciu osiągnąc rozwój. Zwrot przeciwko edukacji tradycyjnej był zatem częściowo pozorny.

Demokracja jest dla Deweya najlepszą formą organizacji społeczeństwa, ponieważ zapewnia, jego zdaniem, największą różnorodność stanowisk spośród innych znanych systemów politycznych. Słowem, im więcej tak pojętej różnorodności, tym więcej doświadczeń i możliwych celów do wyboru i tym większy zakres możliwych do nabycia rozumnych nawyków. Wielość różnych stanowisk zakłada również istnienie indywidualności jednostek. Indywidualność była jednak przez niego postrzegana instrumentalnie, bowiem:

Społeczeństwo postępowe uważa odmiany indywidualne za cenne, ponieważ znajduje w nich środki własnego rozwoju. Stąd społeczeństwo demokratyczne zgodnie ze swym ideałem musi w wychowawczych przedsięwzięciach pozwolić na wolność indywidualną i swobodną grę różnych talentów i zainteresowań (Dewey 1963: 324).

Gdzie indziej pisze, że „Intelektualne warianty tego, co indywidualne w obserwacji, wyobraźni, sądach i pomysłach, są po prostu środkami postępu społecznego" (Dewey 1963: 315). W tym miejscu trzeba stwierdzić, że według pism pragmatysty rozwój jednostek jest jedynie środkiem do rozwoju społeczeństwa - rozwój społeczny jest celem najwyższym. Jeśli więc Dewey uważał, że „wzrastanie jest jedynym moralnym celem" (Dewey 1920: 173), to jedynym celem moralnym jednostek jest przysłużenie się do rozwoju wspólnoty. 


\section{Podsumowanie: rozważania o progresywizmie}

Zajmując się koncepcją rozwoju Deweya, nie da się uniknąć skojarzeń z teorią progresywistyczną, do której zresztą przyporządkowywano amerykańskiego filozofa. Progresywizm stał się wiodącą ideą $\mathrm{XX}$-wiecznych pedagogów, którzy pod wpływem ducha rewolucyjnego chcieli dokonać swoistego zwrotu edukacyjnego, sprzeciwiając się edukacji tradycyjnej opartej w głównej mierze na myśli Johanna Friedricha Herbarta i szkół pruskich. Olbrzymie zainteresowanie takim podejściem do edukacji można postrzegać jako skutek rozprzestrzeniania się w owym czasie prądów intelektualnych, które za cel obrały sobie odejście od tradycyjnych form organizacji stosunków społecznych. W przypadku pedagogiki było to odejście od herbartyzmu.

W ujęciu etymologicznym progresywizm oznacza po prostu rozwój, postęp czy ewolucję (łac. progressus). Gerald Gutek progresywizm ujął jako „to stanowisko, którego reprezentanci zakładają, że poprawa ludzkiej egzystencji i reforma społeczeństwa są nie tylko możliwe, ale także pożądane" (Gutek 2003: 296). Problem ze wskazanym ujęciem tej teorii jest taki, że w zasadzie wszystkie inne teorie również postulują poprawę ludzkiej egzystencji. Co więcej, każdy znany system pedagogiczny opiera się na założeniu, że rozwój wychowanka jest zjawiskiem najbardziej pożądanym bez względu na to, czy miałby to być rozwój przez przyswojenie treści nauczania (Herbart) czy przez całkowite odrzucenie wpływów kulturowych (Rousseau). Ponadto dla wielu „Postęp nie jest teorią, jest faktem” (Postman 2001: 32). Kłopotliwe jest również zdefiniowanie progresywistów poprzez głoszoną przez nich konieczność reformy społecznej, bowiem istnieje wiele innych teorii, w programach których zawarta jest reforma społeczna.

Sam Dewey z pewną dozą niechęci odnosił się do progresywizmu ze względu na zbyt radykalne, jego zdaniem, przejście do nowych form nauczania i wychowywania. Pragmatysta skonstruował w pracy Doświadczenie i edukacja kierkegaardowski konstrukt „albo - albo” odniesiony do rzeczywistości pedagogicznej pierwszej połowy XX wieku (Dewey 2014: 9). Zabieg ten miał uwidocznić, podobnie jak u duńskiego filozofa, kontrast pomiędzy dominującymi wówczas podejściami do pedagogiki: tradycyjnym i progresywistycznym (postępowym). Dewey nie był zwolennikiem traktowania edukacji progresywistycznej jako radykalnego odejścia od dotychczasowych form nauczania, gdyż 
przez to niektórzy ówcześni jemu pedagodzy tworzyli karykaturalne rozumienie nowego podejścia w pedagogice. Wśród pedagogów „Są tacy, którzy nie widzą środka pomiędzy przymusem z zewnątrz a całkowitą wolnością i wybierają jedno albo drugie" (Dewey 1967: 63).

Przeciwstawiając autorytatywność starej edukacji całkowitej wolności dziecka, implicite uważano, że jest ono w stanie samo sobie dostarczać wiedzy i metod jej pozyskiwania. Dewey natomiast napominał, że

Nic nie rodzi się z niczego [...]. Prawdziwy rozwój rozszerza ramy doświadczenia jednostki i każe jej brać udział w doświadczeniu innych; jest przy tym rzeczą niemożliwą osiągnąć go bez jakiegoś pośrednika, który by ułatwiał funkcjonowanie zdolności i zainteresowań, uznanych za wartościowe (Dewey 1967: 63-64).

Amerykański pedagog wyszedł od tezy, że dziecko nie jest w stanie samo sobie podsunąć bodźców do rozwoju swych zainteresowań i na tej podstawie zanegował, stawianą za punkt odniesienia przez niektórych progresywistów, całkowitą wolność ucznia w kształceniu.

Zasadnicza teza progresywizmu Deweya prowadzi do wniosku, że rozwój indywidualny ma prowadzić do rozwoju społecznego - postęp jednostek jest środkiem do postępu wspólnoty. Teoria rozwoju Deweya jest całkiem spójna, lecz nie brakuje w niej elementów, które przywołują pewne wątpliwości, np. sporną kwestią może być to, że rozwój najlepiej realizuje się u uczniów przez praktyczne i kolektywnie zorganizowane zajęcia lub to, „że dziecko i dorosły wciąż tylko myślą i że myślą zawsze w ten sam sposób” (Dewey 1967: LXXVII). Dyskusyjne może być również postrzeganie Deweya jako rewolucjonisty w dziedzinie edukacji. Co prawda przeniósł on środek ciężkości kształcenia $\mathrm{z}$ treści nauczania na metody, lecz w jego systemie, podobnie jak w systemie herbartowskim, występowała tylko jedna metoda nauczania. Poza tym pragmatyzm, jak każda relatywistyczna idea, jest zdolny do „samoobalenia” - za skuteczne można uznać odrzucenie stosowania pragmatyzmu.

Można się spierać o to, czy John Dewey szedł dobrą drogą, wypracowując autorską ideę rozwoju opartą na doświadczeniu refleksyjnym, lecz należy przyznać, że chęć dążenia do rozwoju wychowanków jest niewątpliwie dobrym kierunkiem, chociażby z tego względu, że alternatywami dla rozwoju jest regres lub stagnacja, co nie jawi się jako godna uwagi perspektywa. 


\section{Bibliografia}

Bocheński J.M. (1994). Sto zabobonów. Krótki filozoficzny stownik zabobonów, Kraków: Philed.

Buczyńska-Garewicz H. (1970). Wartośc i fakt. Rozważania o pragmatyzmie, Warszawa: PWN.

Copleston F. (2009). Historia filozofii. Od Benthama do Russella, t. 8, przeł. B. Chwedeńczuk, Warszawa: Instytut Wydawniczy Pax.

Dewey J. (1920). Reconstruction in Philosophy, New York: Henry Holt and Company.

Dewey J. (1922). Human Nature and Conduct: An Introduction to Social Psychology, New York: Henry Holt and Company.

Dewey J. (1963). Demokracja $i$ wychowanie. Wstęp do filozofii wychowania, przeł. Z. Bastgen, Warszawa: Książka i Wiedza.

Dewey J. (1967). Wybór pism pedagogicznych, wybór i oprac. J. Pieter, Wrocław: Zakład Narodowy im. Ossolińskich.

Dewey J. (1988). Jak myślimy?, przeł. Z. Bastgenówna, Warszawa: PWN.

Dewey J. (2014). Dośrwiadczenie i edukacja, przeł. E. Czujko-Moszyk, Warszawa: Warszawska Firma Wydawnicza.

Gałkowski S. (2003). Rozwój i odpowiedzialność. Antropologiczne podstawy koncepcji wychowania moralnego, Lublin: Wydawnictwo KUL.

Gutek G. (2003). Filozoficzne i ideologiczne podstawy edukacji, przeł. A. Kacmajor, A. Sulak, Gdańsk: Gdańskie Wydawnictwo Psychologiczne.

Gutowski P. (2002). Między monizmem a pluralizmem. Studium genezy i podstaw flozofii Johna Deweya, Lublin: Wydawnictwo KUL.

Koczanowicz L. (1994). Jednostka-dziatanie - spoteczeństwo. Koncepcje jaźni w flozofi amerykańskiego pragmatyzmu, Warszawa: Instytut Filozofii i Socjologii PAN.

Miś A. (1998). Filozofia wspótczesna. Gtówne nurty, Warszawa: Wydawnictwo Naukowe Scholar.

Nysler Ł. (2007). Natura ludzka - jaźn - indywidualnośc. Filozoficzno-antropologiczne i etyczne podstawy koncepcji demokracji Johna Deweya, „Studia Philosophica Wratislaviensa”, t. 2, nr 1, s. 55-76.

Postman N. (2001). W strone XVIII stulecia. Jak przesztośc może doskonalić naszq przysztość, przeł. R. Frąc, Warszawa: Państwowy Instytut Wydawniczy.

\section{Netografia}

https://sjp.pwn.pl/slowniki/dojrzałość.html [dostęp: 10.12.2019]. 


\section{ADRES DO KORESPONDENCJI}

Mgr Bartłomiej Zdzisław Krasny

Akademia Ignatianum w Krakowie

Wydział Pedagogiczny

Instytut Nauk o Wychowaniu

e-mail: bartlomiej.krasny@o2.pl 